\title{
Historical Geography of Middle Black Sea (Amisos)
}

\author{
Savaş EĞİLMEZ \\ Ataturk University, Turkey
}

\begin{abstract}
Anatolia peninsula that is a bridge between Asia and Europe has become a house for many diverse nations and settlement for over centuries because of its unprecedented strategic location above mentioned. Every newly-arrived community seems to have captured the native features. Regardless looking what their origins or from where they come this Anatolian culture, local features of which overrides, takes its base from Anatolia's distinctive geopolitical location. Situated in the crossroads of world's most beautiful and important roads Anatolia has lots of different geographical features that are isolated from each other by chain of mountains and include many units. And this allowed the peninsula to have different cultural features in almost every period of history. In Anatolia that has a very dynamic history, one of the most important element changing in time is the name of places. Despite the fact that there is not a precision in the change of names, it is generally related with the language used by prevailing public.
\end{abstract}

Keywords: Middle Black Sea, Amisos, Historical Geography, Anatolia, Samsun

Till one thousand years ago, that's arrival of Turks, different ethnic groups in Anatolia used very different place names from current place names in order to identify the land in which they live. For instance, for the city what we call currently as Eskişehir they named it as Donylaron or for Kızılırmak they used Holys.

However, there are still lots of place names that are not changed at all or changed slightly such as Dinope-Sinop, Turos-Toros ${ }^{1}$, or Touros-Toros.

The field currently known as middle Black Sea stretches from Miletus small stream, which is situated in Ordu city, to the west of down Kizılirmak water basin ${ }^{2}$. Made up with tectonic rabbets where Black Sea shores and Canik mountains and Kelkit, Yeşilırmak rivers are situated middle Black Sea's back neighborhood composes two different parts of this area. While the mountains range up to the parts of South, Samsun, Ordu, and Giresun in the name of Canik up to Yeşilırmak shores, they lose their height and look like a mesa and many plateaus take place there.

In Black Sea region which has a wide stream system besides Kızılırmak and Yeşilırmak taking place between Samsun and Trabzon, Melet stream, Terme small stream, Miletus water, Harşit small stream, Değirmendere and Çoruh and Kelkit rivers which situate a little more south are the main sources of middle and west Black Sea. Above-mentioned rivers and neighborhood fields have become important settlement areas for many communities throughout history both while entering to the region and while spreading through Anatolia ${ }^{3}$.

\footnotetext{
Atatürk University, doctorate, assistant professor, Faculty of Letters, History Department, 25240-Erzurum/Turkiye.

1 SEVİN V. Anadolu'nun Tarihi Coğrafyast, I. Ankara, 2001, p. VIII.

2 ERDOĞDU İ. “Orta Karadeniz Bölgesi’nin Tarihi Coğrafyası”, Orta Karadeniz Kültürü, pp. 21-32, Ankara, 2005 , p. 22.

3 Nİ̧̧ANCI A., "Karadeniz Bölgesi’nin İklim Özellikleri ve Farklı Yöreleri”, I. Tarih Boyunca Karadeniz Kongresi Bildirileri, (13-17 Ekim 1986) Samsun 1988, pp. 223-231; ERİNÇ S. "Kuzey Anadolu Kenar Dağlarının Ordu-Giresun Kesiminde Landşaft Şerifleri”, Türk Coğrafya Dergisi, 3, VII-VIII, Ankara, 1945, pp. 119-130.
} 
Thanks to its water sources and other features that are suitable to live, middle Black Sea region has become a settlement area or a transition place for many nations.

In ancient sources, the name of Black Sea was Pontos ${ }^{4}$. It means "sea" in Helen language ${ }^{5}$. According to another source, the public living in the region named Black Sea as Pontos-Aexenios which means to be hostile against foreigners ${ }^{6}$.

Afterwards, when Freks improved themselves in shipping and they obtained the fish, mine, timber, cereals, slaves, and furs of Black Sea they named it Pontos-Euxenios which means to be friendly towards foreigners ${ }^{7}$.

The reasons why the adjective "black" was given to the sea in all languages are derived of its violent storms and horrifying waves besides its black sand. In the same time being surrounded by mountains from every side looks dark because of clouds brought by north and west winds. Apart from these, there is another account that tells us; once upon a time there used to be a nation called Kimri in Pontos and because the nation loved black symbolizing joy called it black. In addition to these, Arabs call Black Sea as Bahr-1 Esved, Bundus, Russians call it as Kizarne More ${ }^{8}$.

Assyrian sources have always called Black sea as Pontos 9 .

Ancient writers used word Pontos mostly for Black Sea shores and the cities situated along this shore. Later on, while Pontos was used to identify only South shores in Hellenistic period with the constructions of cities in the region, the region was called as Capadocia or Pontos Capodocia in Greek sources. This name was shortened in time and only Pontos was given to the region. At the beginning, the name was thought to identify the lands of Pontos Kingdom and its new capital city Amasya but afterwards Little Armenia situated in Strabon and Inside Pflogonya were added to Pontos land by western scientists ${ }^{10}$.

According to this situation, as a geographical land Pontos's borders included the lands from which Çoruh lie up to Bartın small stream and to small north parts of Asia plateaus. To be more clear, the land identified as Pontos included the north of Karasu-Aras mountains range; Karasu valley, so Erzincan and Kemah; the north of Tecer Mountains range, the land including Çekerek small stream, so Zile and Turhal situated in the nort of Zile and today's Amasya and almost whole of Samsun, in short the whole land taking place in the east of Kizilirmak $^{11}$.

The date given by old historians and geographers about the activities made in order to establish new settlement areas is not enough to come up with an idea about this topic. The establishment period of many Greek settlements were not recorded in Antic sources. That's why neither establishment date of many cities nor with which main cities help they were founded have been known so far.

In Greece land, there is not enough room to support increasing population. For owners of farms and workplace employed cheap slaves, free citizens got jobless. Due to political parties and social class distinctions,

\footnotetext{
4 The Geography of Strabon, trans., H. L. Jones, vols. 1-8, London, 1917-1932, VII, 3.6.

5 UMAR B., Karadeniz Kappadokia'sı (Pontos), Ankara, 2000, p. 1.

${ }^{6}$ BIJIŞKYAN P. M. Karadeniz Kıyıları Tarih ve Coğrafyası (1817-1819). Trans., Hrand D. Andreasyan, İstanbul, 1969, p. 35.

7 Ibid., p. 35; UMAR B., op. cit., p. 2; ATASOY S. Amisos (Karadeniz Kiyısında Antik Bir Kent). Samsun, 1997, p. 2.

8 BIJIŞKYAN P. M., op. cit., p. I.

9 IŞIK, Adem. Antik Kaynaklarda Karadeniz Bölgesi. Ankara, 2001, p. 2.

10 ÖZSAİT M. “Anadolu'da Hellenistik Dönem”, Anadolu Uygarlıkları, 2, Görsel Anadolu Tarihi Ansiklopedisi, pp. 333-378, İstanbul 1982, p. 350. Pontos Kingdom is surrounded by vassals of Roman Impire; Cappadocia, Paphlagonia and Bithynia. ROSTOVTZEFF M. and ORMEROD H. A., "Pontos and its Neighbours: The First Mithridatic War", The Roman Republic 133-44 B.C., CAH IX, 1971, 211-260, s. 234; ÇİĞDEM S., Gümüşhane Bölgesinin Tarih ve Arkeoloji Araştırmaları, Erzurum, 2008 , p. 37.

11 UMAR B., op. cit., p. 7.
} 
economic situation got rotten. It was necessary to find cheap food stuffs. Furthermore, there was need for cheap raw materials and slaves to keep industry strong. There had to find outside markets to sell the surplus productions, as well ${ }^{12}$.

Before Greeks arrived at Black Sea they settled in Çanakkale Bosphorous/Helespontos and Sea of Marmara/Propontis shores in the mid of B.C. 7th century. They founded small cities dependent on agriculture ${ }^{13}$.

Greeks went to Black Sea after Marmara because there were plenty of fish there. Wheat, cattle, sheep, and horse were raised in Kimmer/Kerç Bosphorus in north and Iskit parts. Because Iskit noble men became rich thanks to stock-breeding and agriculture it was a good market for luxury goods of Aegean. Thanks to that west, south and south Black Sea shores are forested, these regions are very rich in terms of timber and fur animals. There were mines in south Black Sea shore and trade roads leading to Mesopotamia began here. Moreover, native public living in neighborhood of Black Sea as small political communities gave much importance to the shores. To them trade products were important ${ }^{14}$.

Except for the date when Greeks started to settle here, sources do not give enough information to come up with an explicit idea about the topic. Establishment dates of many Greek settlements were not recorded ${ }^{15}$.

It was claimed that most of the cities situated in the north shore were founded by Milets. It was stated in Psevdo-skymnos as follows: The community who sent to most plentiful colonies from İonia is Miletus and named Black Sea as hospitable contrast to its former name meaning xenophobia because of pressures against foreigners ${ }^{16}$.

It will not be wrong to say that Amisos was established by Greeks colonialists. When we tied to analyze the history of the city according to written records we come across fragmented and sometimes misleading information. Neither tablets nor city coins give explicit information about the founders and the dates of foundation.

Table 1

Foundation of Amisos According to Antique and Modern Historians

\begin{tabular}{|l|l|}
\hline Historians & Opinions \\
\hline Strabon & According to Thaempompos, it was established by Miletos \\
\hline Ps. Skymnos & It was a colony of Phokaia \\
\hline F. Bilabel & It was established by Miletos and Phokaias \\
\hline J. L. Myres & It was established by Miletos and Phokaias \\
\hline F. Miltner & It was established by Miletos in B.C. 8 century \\
\hline C. Müller & It was a colony of Athenas \\
\hline M. Maksimavo & It was established by Phokaias (B.C. 631 ) \\
\hline R. M. Cook & It was established by Miletos and Phokaias \\
\hline N. Ehrhardt & It was established by Miletos \\
\hline N. G. Hammond & It was established by Miletos with help of Phokaia in B.C. 8 century \\
\hline F. Lasserre & It was established by Miletos \\
\hline C. Roebuck & It was established by Phokaias (B.C. 600$)$ \\
\hline
\end{tabular}

12 ROEBUCK C. Ionian Trade and Colonization. New York, 1959, p. 9.

13 BOARDMAN J. The Greek Overseas, Their Early Colonies and Trade. London, 1988, p. 241.

14 ATASOY S. op. cit., p. 2.

15 KESKİN A. M.Ö 71'de Roma Imparatorluğu'nun İşgaline Kadar Amisos. Berlin, 2005, p. 10.

16 KORENJAK M. Die Welt-Rundreise eines anonymen Griechischen Autors (Pseudo-Skymnos). Hildesheim, Zürich, New York, 2003, p. 736. 
However, even if the information is fragmented, Amisos takes place in ancient writings because of its strategic location situated between Sinope/Sinop in west and Trapezus/Trabzon in east and on a gulf coming deeply towards the land.

From the researches made in Amisos field the oldest human traces were excavated in Tekeköy. Stone instruments and animal bones belonging to Mesolithic period were found here in kaya shelters ${ }^{17}$. However, outdoor settlements taking place in this region were seen in Chalcholithic period in its oldest example. During the period from Chalcholithic to iron period (B.C. 1200-700) settlement number was 74.

Through scientific excavations made in Tekeköy, Dönertepe, Kaledruğu mound and İkiztepe, it was seen that all settlements were in the form of village and they were founded by small communities. It was also seen that the public living in the region lived in wooden houses, made a living by haunting, fishing and stock-breeding; they knew fabric and leather, they made weapon, tool, and jewels from pure copper at the beginning but then they used arsenical copper to make them ${ }^{18}$.

The material and technical features, which were discovered in Dündartepe, made from fences and covered with a thick mud became the tradition of construction in Black Sea field.

After analyzing post and pans it was discovered that Amisos field had strong relations with south Aegean islands (Samos Tigani, Kios Emporion) in late Chalcholithic -Bronze period, north Greece ( Sitagroi, Dikilitaş, Paradimi), Bulgarian (Varna, Karanova) and Romania (Cernavoda) cultures. All these relations show us that there was a shore shipping ${ }^{19}$.

Between middle Anatolia and Mesopotamia it was most probable that the trade established by Assyrian merchants was broaden up to Amisos fields. Depending on these data it may be said that a trade road starting from İkiztepe stretches to Mesopotamia passing over Dündartepe, Horoztepe, Maşathöyük, Kayseri, Pınarbaşı, Gürün, Drende, Arslantapa, and Kargamış ${ }^{20}$.

The city what we call as Samsun today was established in shore lowland situated between Galley Fener Cape and Derbent Çadır cape. And the lowland is composed of alluvial carried by many streams and its width is between $300-50 \mathrm{~m}$.

Düztepe over which Ancient Amisos is situated is about $3 \mathrm{~km}$ north west of Samsun and its height is from $50 \mathrm{~m}$ up to $165 \mathrm{~m}$ from sea to inside and from north to south. It has a triangular shape and its width is about 15 $\mathrm{km}$. The names such as Black Samsun, Old Samsun, and Toroman hill were given to this hill that becomes narrower towards south. North side of hill together with the small valley turns into four fingers shape. There are streams called Dark watercourse and Baruthane Samsun watercourse in two valleys. In the direction of east and west mountain ranges which run parallel along the coastline Black Sea and do not permit any gateway to inside of Anatolia from shore loses their height and continuation in the south of Amisos ${ }^{21}$. Amisos has always been a door opened to Black Sea of middle Anotolia from earliest dates on. Passing the Kilit gateways becomes the beginning point of north south way leading Syrian $^{22}$. Strabon takes the way between Issos gulf and Amisos as

\footnotetext{
17 KÖKTEN K., ÖZGÜÇ T., \& ÖZGÜÇ N. “1940-1941 Yılında Türk Tarihi Kurumu Adına Yapılan Samsun Bölgesi Hakkında İlk Kisa Rapor”, Belleten IX, pp. 361-400, Ankara 1945, p. 383.

18 BİLGi Ö. "Metal Objects from İkiztepe-Turkey", Beitrage zur Allgemeinen und Vergleichenden Archaologie Mainz am Rhein 9-10, 119-219, (1990), pp. 167-169.

19 THISSEN L. "New Insigts in Balkan-Anatolian Connections in the Late Chalcolithic: Old Evidence from Turkish Black Sea Littoral." AS 43 1993, pp. 220-221.

${ }^{20}$ BİLGİ Ö. "Metal Objects from İkiztepe-Turkey." p. 175.

21 ATASOY S. op. cit., p. 2.

${ }^{22}$ RAMSAY W. M. The Historical Geography of Asia Minor. London 1890, p. 268.
} 
Ismus and gives its distance as three thousand stadya ${ }^{23}$. However, Plirius takes this distance as 200 Roma miles, though. Two main roads near Amisos fields were determined by French, first of which is Kastamonu stretching to east-west direction and Pompeiopolis/Taşköprü, Boyabat, Phazemon/Vezirköprü, Havza, Laodikeia/Ladik, Kaberira/Niksar way, and the second one is Amiso, Hamaönü, Chiliokoman/Suluova way. All stretch north-east direction. These two roads intersect Ladik fields ${ }^{24}$. It used to take six or seven days from Amisos to Totat and fifteen days from Amisos to Aleppo/Halep by a vehicle in A.D. 15th century ${ }^{25}$. The presence of caravansaries on the road proved that this road used to be important in 17 th and 18th centuries as well ${ }^{26}$. The distance between Samsun and Tarsus takes 380 kilometers with current highway.

It seems that Amisos's old public is Enets. We take our present information about who Enets are and where they lived from Strabon. Strabon makes a comment in his work as follows: "When Enets went to help Trojans, they had emigrated from Levkosyrs country. Then they left Trojan by ships reconciling with Thraks and then they settled to Adria and neighborhood of it. Enets who did not take place in the war became Cappadocia" ${ }^{\text {27. }}$.

Two forms of the city's historical names became Amisos and Samisos in Helen and Greek language. The actual name was Amisso, that's Am(a)-issa Mother (mother goddesses) settlement city which comes from either Luvian language or a related language to it but most probably from Cappadocia language. The record from Samissa was derived from Amissa that meant good, beautiful, holy, and blessed such as S(wa)-A(a)issa Blessed Mother's ( Mother goddess) settlement city ${ }^{28}$.

In Helen language Amisos means "without grudge".

What captures our attention is that the city shown as Simisso in Medieval period Italy (Pisa city) is shown as Sinussa. Sinussa name is particularly interesting because adjacent city Sinop was used as Sinuwa in Hittite documents.

While the name Samisos turned into Samsun in Turkish language it turned into Sampson in medieval Italian language. Italians used Sampson also for ancient Prinene city's remains near Söke in medieval period and likewise in Turkish language the same place was called still Samsun and Mykle mountain that is just over there, was called as Samsun mountain we come across again Samsun name in different parts of Anatolia ${ }^{29}$.

\section{Coins of Amisos}

For it is situated in the only one plain gateway, Amisos started to become popular B.C. 4th century as the most important place of Pontos region in terms of economy. It was estimated that Amisos had an economic relation with the regions that had its coins from this date on.

Being Pontos mint, that's economic center, Amisos conveyed its coins to every field from the Balkans Mesopotamia, Egypt to Middle Asia even if we have found a little amount of them. That Amisos coins spread a wide field signals that there was overseas trade. However, this situation does not prove the presence of

\footnotetext{
${ }^{23}$ STRABON, op. cit., XIV. 5.22.

${ }^{24}$ FRENCH D., "Roma Yolları ve Miltaşları 1984", III. Araştırma Sonuçları Toplantısı 1985, 143-146, Ankara, p. 145.

25 BRYER A. \&WINFIELD D. The Byzantine Monuments and Topography of the Pontos, Dumbarton Oaks Trustees for Harward University. Washington, D.C. 1985, p. 92.

26 YUVALI A. “13.yy'da Karadeniz Ticareti”, 2. TBKKB 1988, Samsun, 1990, pp. 233-240.

27 Strabon, XII. 3.25.

28 UMAR B. op. cit., p. 80.

${ }^{29}$ UMAR B. op. cit., p. 81.
} 
commercial relations between Amisos and the places where coins were found ${ }^{30}$. It is only considered as an assumption that Samsun Archeology museum presents a rich collection of numismatics 7,500 coins in total ${ }^{31}$.

Amisos up city covers 44 hectare field surrounded by sea in east and north and being on the plain of Toroman hill restricted with Baruthane watercourse in west. What we understand from the remains from early Byzantium period is that settlements did not happen after early Byzantium period in Up City.

Down city is situated near ancient port. It seems that the living style was not different from other Greek cities. There were places to stock import and export commodities in down city during the time the trade was dense. Slaves, sailors, merchants, and passengers who carried commodities brought from overseas countries created a big chaos. Restaurants, entertainment spots served for this crowd. When it comes to vegetables and fruits grown in fertile lowlands, villagers took them here to sell ${ }^{32}$.

Down city developed in Hellenistic period when the trade became widespread. Afterwards, the city situated in the north west of Samsun and the castles were founded by Seljukian merchants.

If we do not take into consideration that Samsun was used as Seljuks and Mongols mints between the years 1233-1248, Samsun was not considered as an important region in Ottoman Empire as in Seljukian inspite of the fact that it was a gateway having a commercial density. However, Amisos that was near enough even to shoot arrows was quite important compared with Samsun. As far as it is known Italians arrived at the region in 1212 for the first time. Genovese founded a small castle and consul in $1285^{33}$. Greeks and Armenians composed of the majority population in the region and they provided protection for there. A Spanish embassador having visited here in 1,404 says that "There are two castles in this city. One of them belongs to Genovese and the other one belongs to Turks" ${ }^{\$ 4}$. So we could not embark on the port and anchored open area. Venetians sent three ships to the region with the aim of trade in 1421. Italian sources last told about Genoa colonies in 1424.

Genovese left the city burning down. However, Ottoman states belonging to the years 1481-1512 still talk about the presence of six Frank families ${ }^{35}$.

Turks searched the possibilities of reaching to the sea along Amisos. They penetrated into the region during ten years and established an arrival settlement next to Amisos. While Samsun was under the rule of Turks during the years between 1194-1204, Amisos remained Greek. Till 14th century Turkish Samsun and Byzantium Amisos became different settlements ${ }^{36}$.

Long protection walls of Hellenistic walls still used to be till the beginning of 19th century. One might come across even in 1935. St. Peter graveyard taking place in the south of Acropolis was still a kilt center in 1905. There is a tablet that has a strong monastery in west side and St. John Prodromos church ${ }^{37}$. It is told that there is a cistem, a cave, a tower made in Byzantium period, and a square building in the south of the region $^{38}$.

${ }^{30}$ WEIMERT H. Wirtschaft als landschaftsgebundenes Phanomen, die antike LAndschaft Pontos, Frankfurt am Main, 1984, pp. 121-122.

${ }^{31}$ KESKIN A. op. cit., p. 32.

32 ATASOY S. op. cit., pp. 52-53.

${ }^{33}$ BRYER A. \& WINFIELD D. op. cit., p. 94.

${ }^{34}$ Ruy Gonzalez de Clavijo, Embassy to Temarlane, 1403-1406, trans., Guy Le strange, London, 1928, p. 108.

${ }^{35}$ BRYER A. \& WINFIELD D. op. cit., p. 94.

${ }^{36}$ BRYER A. \& WINFIELD D. op. cit., p. 93.

${ }^{37}$ BRYER A. \& WINFIELD D. op. cit., pp. 94-95.

${ }^{38}$ HAMILTON W. J. Researches in Asia Minor, Ponyus and Armenia, London, 1842, p. 290. 
Furthermore, Hamilton talks about St. Theodore church which turned into a mosque afterwards in the south on the edge of Acropolis ${ }^{39}$.

Today, in current Samsun there are not any remains from ancient Amisos/Samisos city and medieval Gavur Samsun castle after the fire it was called Black Samsun fields.

Because of the fire which gives Black adjective to that region even the traces of them were not remained. But still some small foundlings were excavated after radar installations and other basic excavations in the region.

Among the foundlings, particularly mosaic base slab that belongs to Roman ruling period is worth talking about. Thetis, her son Akhilleus, Nereids and sea dragons are portrayed as very colourful in the mosaic ${ }^{40}$.

The name of the region in Turkish sources is Canik. One of the earliest texts used Canik is Danismendnâme that was written in 1244-1245. According to this work Canik region is described as surrounded by Black Sea in north side, Samsun in west side, Karakuş in south (it is Akkuş shire currently) Trabzon in east, and Bulgarian mountains. With Anatolia Seljuk spreading to the region it started to take place in the records and it included Aksaray, Estrebadi, and current Samsun according to records of Mineccimbaş1. Later on, Canik included a much wider field in İbn Bibi and Anonymous Selçuknâme and referring to the lands of Trabzon Rum state "Canik ruler" was used for the Kommenos king ${ }^{41}$. So it is clear that Canik name was widely used long before Ottomans came to the region. Ottomans used Canit, Mülk-i Canit for the lands belonging to Trabzon State and they used Tekfur-i Canit, Melik-i Canit, or Canit for the rulers who rule Trabzon state. While Gibbons was talking about emirates in Anatolia in 16th century he described Canik as the region between Samsun and Sinop ${ }^{42}$. Although the field described as Canik's borders sometimes becomes wider and sometimes becomes narrower, it is stated that the region stretches at least from Trabzon to current sea shores of Samsun's west borders and to Amasya, Tokat cities in east ${ }^{43}$.

Amisos is in the middle of Black Sea and it has good relations with back side of it and it has fertile soils around itself. Besides these features, it stands at the beginning and end point of south-north ancient road ${ }^{44}$. All these advantages make it important enough to take part in history. That the information about it is fragmented makes its history hard to write.

That settlement areas were becoming wider during Roman period shows its being crowded rather than it lost its importance. Therefore, Amisos situated over Toroman hill sides descended beside the port and it became wider when Down city was established. Even though there was a shoreline here, with the coins scattered overseas countries we know that trade was carried out successfully ${ }^{45}$.

That Seljuk did not touch Amisos in 13th century but later established Samsun shows how successful Amisos residents were even in Medieval period. For Seljuk did not know the trade well they lived next to Amisos residents and made us of their trade faculty.

Samsun is still a trade center and this is a continuation and evidence coming for its history and geography.

\footnotetext{
39 Ibid., p. 291.

${ }^{40}$ UMAR B. op. cit., p. 85.

41 ERDOĞDU İ. op. cit., p. 27.

42 GIBBONS Adams. Osmanlı İmparatorluğu'nun Kuruluşu, trans., AYVERDİ M., Ankara, 1998, p. 245.

43 DİLCIMEN K. Canik Beyleri, Samsun, 1940, p. 8.

44 VRYNOSI S. The Decline of Medieval Hellenism in Asia Minor and the Process of Islamization from the 15th Century, London, 1971, p. 32.

45 ATASOY S. op. cit., p. 107.
} 


\section{References}

ATASOY, S. (1997). Amisos (Karadeniz Kiyısinda Antik Bir Kent). Samsun.

BIJIŞKYAN, P. M. (1969). Karadeniz Kıyıları Tarih ve Coğrafyası (1817-1819). Trans. and Notes, Hrand D. Andreasyan. İstanbul.

BİLGİ, Ö. (1990). Metal objects from İkiztepe-Turkey. Beitrage zur Allgemeinen und Vergleichenden Archaologie Mainz am Rhein, 9-10, 119-219.

BOARDMAN, J. (1988). The Greek overseas, their early colonies and trade. London.

BRYER, A., \& WINFIELD, D. (1985). The Byzantine monuments and topography of the Pontos, Dumbarton Oaks trustees for Harward University. Washington, D.C.

ÇİĞDEM, S. (2008). Gümüşhane Bölgesinin Tarih ve Arkeoloji Araştırmaları. Erzurum.

DİLCIMEN, Kâzım. (1940). Canik Beyleri. Samsun.

ERDOĞDU, İ. (2005). Orta Karadeniz Bölgesi'nin Tarihi Coğrafyası. Orta Karadeniz Kültürü̈, 21-32, Ankara.

ERINÇ, S. (1945). "Kuzey Anadolu Kenar Dağlarının Ordu-Giresun Kesiminde Landşaft Şerifleri.” Türk Coğrafya Dergisi, 3, VII-VIII, 119-130. Ankara.

FRENCH, D. (1985). Roma Yolları ve Miltaşları 1984. III. Araştırma Sonuçları Toplantısı, 143-146.

GIBBONS, A. (1998). Osmanlı Imparatorluğu'nun Kuruluşu, çvr., M. Ayverdi. Ankara.

HAMILTON, W. J. (1842). Researches in Asia Minor, Ponyus and Armenia. London.

IŞIK, A. (2001). Antik Kaynaklarda Karadeniz Bölgesi. Ankara.

KESKIN, A. (2005). M.Ö 71'de Roma İmparatorluğu'nun İsgaline Kadar Amisos. Berlin.

KORENJAK, M. (2003). Die Welt-Rundreise eines anonymen Griechischen Autors (Pseudo-Skymnos), Hildesheim, Zürich, New York.

KÖKTEN, K., ÖZGÜÇ, T., \& ÖZGÜÇ, N. (1945). 1940-1941 Yılında Türk Tarihi Kurumu Adına Yapılan Samsun Bölgesi Hakkında İlk Kısa Rapor. Belleten IX, 361-400, Ankara.

NIŞANCI, A. (1988). Karadeniz Bölgesi’nin İklim Özellikleri ve Farklı Yöreleri. I. Tarih Boyunca Karadeniz Kongresi Bildirileri, (13-17 Ekim 1986) Samsun, 223-231.

ÖZSAİT, M. (1982). Anadolu'da Hellenistik Dönem. Anadolu Uygarlıklarl, 2, Görsel Anadolu Tarihi Ansiklopedisi, 333-378, İstanbul.

RAMSAY, W. M. (1890). The historical geography of Asia minor. London.

ROEBUCK, C. (1959). Ionian trade and colonization. New York. 